\title{
FARMING PRACTICES FOR CLIMATE CHANGE ADAPTATION OF ONION FARMERS IN THE PHILIPPINES
}

\author{
John Rey B. Quiñones ${ }^{1 *}$, Roel S. Ang ${ }^{1}$ \\ ${ }^{1 *}$ College of Arts and Sciences, Nueva Ecija University of Science and Technology, \\ Cabanatuan City, 3110, Philippines;
}

"Corresponding Author John Rey B. Quiñones, e-mail: johnrey201334@gmail.com;

Received September 2020; Accepted October 2020; Published November 2020;

DOI: https://doi.org/10.31407/ijees10.420

\begin{abstract}
Climate change is one of the most complex issues we are facing today. Farming is affected by the following effects of climate change: weather, natural disaster, and occurrence of pest and diseases. This study employed the qualitative approach and revealed the farming practices of onion farmers. Onion farmers in the Philippines are between 38 to 57 years of age, male, married, and with high school level of educational attainment. The respondents described their experienced effects of climate change such as excessive coldness, excessive rainfall, inconsistent weather patterns, increased number of pests due to high humidity and excessive rainfall. Their climate change adaptation practices include adjusting the dates of planting season, constructing irrigation canals to prevent flooding, mulching, and using home-made pesticides. The finding of the study also revealed gaps in the scientific knowledge of onion farmers and it is recommended that interventions be developed to address these gaps. Further, it is recommended that the results of this study be forwarded to other academic, research units, and LGUs, in order to help them craft policies that will help onion farmers as they adapt to climate change.
\end{abstract}

Keywords: Causes and Effects of Climate Change, Climate Change Adaptation, Collaizi's Method of Analysis, Disaster, Farming Practices Pest and Diseases, 